\title{
BULBOPHYLLUM KARBIANGLONGENSIS (EPIDENDROIDEAE), A NEW SPECIES FROM ASSAM, INDIA
}

\author{
Khyanjeet Gogoi ${ }^{1,3}$ \& Rituraj HondiQui ${ }^{2}$ \\ ${ }^{1}$ The Orchid Society of Eastern Himalaya (TOSEHIM), Regional Orchids Germplasm Conservation \& \\ Propagation Centre (Assam Circle), Daisa Bordoloi Nagar, Talap, Tinsukia 786 156, Assam, India. \\ ${ }^{2}$ Kaziranga National Orchid \& Biodiversity Park, Golaghat, Assam, India. \\ ${ }^{3}$ Author for correspondence: khyanjeet.gogoi@gmail.com
}

\begin{abstract}
AвSTRACt. A new epiphytic Bulbophyllum belonging to section Cirrhopetaloides is described from tropical mixed evergreen forests of Karbi Anglong (Assam, India) with coloured photographs and line drawings. It is allied to the Bulbophyllum bicolor, B. venulosum, and B. blaoense, but differs in the size and shape of pseudobulbs, the shape of the leaf blade, and flower size. A detailed description with corresponding color photos and information on the habitat is provided.
\end{abstract}

Key words/Palabras clave: Bulbophyllum bicolor, Bulbophyllum blaoense, Bulbophyllum sect. Cirrhopetaloides, Flora of India, Flora de India, plant taxonomy, taxonomía de plantas

Introduction. The genus Bulbophyllum Thouars (1822) is one of the largest plant genera in Orchidaceae, with over 2200 species distributed in the tropics and subtropics of the world (Vermeulen et al. 2014). Currently, more than 121 species have been recorded in India (Misra 2019). Gogoi (2019) reported 40 species of Bulbophyllum from the state of Assam. During a field trip to the forested area of Hamren of Karbi Anglong District of Assam on 14 March 2018, an unknown Bulbophyllum species was found without flowers, which could not be determined immediately. Therefore, the orchid was put in cultivation at the Regional Orchids Germplasm Conservation \& Propagation Centre (Assam Circle), where plants flowered under observation on 20 May 2021. Unfortunately, the species could not be matched with any existing species in the region and adjacent areas.

Thorough morphological studies revealed that the new species belongs to Bulbophyllum section Cirrhopetaloides Garay, Hamer \& Siegerist (Vermeulen et al. 2014). It is characterized by creeping rhizome; 1-leaved pseudobulbs; subumbellate raceme arising from the base of pseudobulbs; free dorsal sepal, entire, erose, fimbriate, ciliate, or paleate along the margin; lateral sepals glabrous, twisted at the base and adnate (entirely or in part) along one or both margins. Petals are denticulate or fimbriate along the margin; lip simple; stellidia usually shorter about half of the column length, usually with tooth above and wing below. Pollinia 4, without stipe. The section contains around 19 accepted species distributed from Sri Lanka, India, China, Taiwan, Japan, Myanmar, Thailand, Indochina, Peninsular Malaysia, Sumatra, Borneo, and the Philippines.

After careful examination and comparison with existing species with the help of available literature (Averyanov et al. 2015, Chen et al. 2009, Chowdhery 1998, Gale et al. 2010, Gogoi 2014a, 2014b, 2018, 2019, Gogoi \& Yonzone 2013a,b,c, Hegde 1917, Hooker 1890, King \& Pantling 1898, Lucksom 2007, Misra 2019, Pearce \& Cribb 2002, Pradhan 1979, Rao 2010, Singh et al. 2019) and critical examination of herbarium specimens deposited in ASSAM, ARUN, CAL and type images present in K, E, and PE. As a result, it is confirmed to be a hitherto undescribed species. Hence, we describe the same here along with colour plates and line drawings. We also compare it with is closest allies, i.e., B. bicolor Lindl., B. venulosum J.J.Verm. \& A.L.Lamb and B. blaoense Tich \& Diep ex Aver. \& Tich.

Materials and methods. The measurements and species description were made from living plants. Type is deposited at the Herbarium of the Orchid Research Centre Tipi, Arunachal Pradesh (OHT) and Herbarium of The Orchid Society of Eastern Himalaya (TOSEHIM), Regional Orchid Germplasm Conservation and 
TABlE 1. Diagnostic features of Bulbophyllum blaoense, B. bicolor, karbianglongensis, and B. venulosum.

\begin{tabular}{|c|c|c|c|c|}
\hline Character & B. blaoense & B. bicolor & B. karbianglongensis & B. venulosum \\
\hline Rhizome & $\begin{array}{l}\text { Rigid, semi-woody, } 0.2-0.3 \mathrm{~cm} \text { in } \\
\text { diameter }\end{array}$ & $\begin{array}{l}\text { Several-noded } \\
\text { rhizome } 0.25-0.5 \mathrm{~cm} \\
\text { in diameter }\end{array}$ & Short, $0.5 \mathrm{~cm}$ diameter & $\begin{array}{l}0.15-0.25 \mathrm{~cm} \text { diameter, } \\
1.8-9.0 \mathrm{~cm} \text { long }\end{array}$ \\
\hline Pseudobulbs & $\begin{array}{l}\text { Distant from each other } 1-3 \mathrm{~cm} \text {, } \\
\text { broadly ovoid to almost globular or } \\
\text { slightly oblate, } 0.5-0.7 \mathrm{~cm} \text { tall and } \\
\text { wide, young enveloped by tubular } \\
\text { sheaths }\end{array}$ & $\begin{array}{l}\text { Distant from each } \\
\text { other } 3.5-5.5 \mathrm{~cm} \text {, } \\
\text { ovoid, } 2-2.5 \times 1.2- \\
1.5 \mathrm{~cm} \text {, prominently } \\
\text { angled, enclosed in } \\
\text { a basal sheath that } \\
\text { withers with age }\end{array}$ & $\begin{array}{l}\text { Clustered together, } \\
\text { narrowly ovoid to conic, } \\
1.5-2.5 \times 0.8-1.8 \mathrm{~cm} \text {, } \\
\text { with } 3 \text { bracts sheathing } \\
\text { towards the base }\end{array}$ & $\begin{array}{l}1.2-1.8 \times 0.7-1.2 \mathrm{~cm}, \\
\text { distinctly } 4 \text { angled, ovoid to } \\
\text { ellipsoid }\end{array}$ \\
\hline Leaves & $\begin{array}{l}\text { Sub-sessile, broadly lanceolate } \\
\text { to narrowly ovate, } 6-12 \times 1.4-2.5 \\
\mathrm{~cm} \text {, acute to shortly unequally } \\
\text { bilobed }\end{array}$ & $\begin{array}{l}\text { Oblong, channeled, } \\
11-16 \times 2.5-4 \mathrm{~cm} \\
\text { obtuse. }\end{array}$ & $\begin{array}{l}\text { Elliptic-lanceolate, } \\
15-17.5 \times 1.4-1.6 \mathrm{~cm} \text {, } \\
\text { acute to acuminate, } \\
\text { channeled. }\end{array}$ & $\begin{array}{l}\text { Ovate, } 3.1-12.5 \times 2.6-4.3 \\
\mathrm{~cm}\end{array}$ \\
\hline Inflorescence & Umbel, 7-12 cm long, 2- 5 flowers & $\begin{array}{l}\text { Subumbellate, } 5-7.5 \\
\mathrm{~cm} \text { long, with 3-6 } \\
\text { flowers }\end{array}$ & $\begin{array}{l}\text { Subumbellate, 15-19 } \\
\mathrm{cm} \text { long, 5-10 flowers }\end{array}$ & $\begin{array}{l}\text { Subumbellate, } 8-14 \mathrm{~cm} \\
\text { long, } 4-9 \text { flowers }\end{array}$ \\
\hline Floral bracts & $\begin{array}{l}\text { Slightly concave, acuminate, } 0.3- \\
0.4 \times 0.1-0.1 .5 \mathrm{~cm}\end{array}$ & $\begin{array}{l}\text { Narrowly-ovate, } \\
0.5-0.7 \times 0.15-0.2 \\
\mathrm{~cm}\end{array}$ & $\begin{array}{l}\text { Lanceolate, acute, } \\
0.4-0.5 \times 0.1 \mathrm{~cm}\end{array}$ & $0.2-0.35 \mathrm{~cm}$ long \\
\hline Flowers & $\begin{array}{l}\text { Tepals dull pale yellow marked } \\
\text { with purple-brown, purple-violet } \\
\text { at apex; lateral sepals almost } \\
\text { white striped with dull purple along } \\
\text { nerves; lip adaxially light dull } \\
\text { yellowish, little flushed with purple } \\
\text { at the base, almost white spotted } \\
\text { with light purple at abaxial surface }\end{array}$ & $\begin{array}{l}\text { Tepals pale greenish- } \\
\text { yellow with purplish- } \\
\text { red to maroon dots } \\
\text { and flecks forming } \\
\text { lines on both sur- } \\
\text { faces, apex of dorsal } \\
\text { sepals and petals } \\
\text { tinged deep purplish- } \\
\text { red }\end{array}$ & $\begin{array}{l}\text { Tepals greenish yellow } \\
\text { with purple nerves, lip } \\
\text { dark red/purple with } \\
\text { prominent median white } \\
\text { band running from the } \\
\text { base to the apex }\end{array}$ & $\begin{array}{l}\text { Tepals white or slightly yel- } \\
\text { low, sometimes suffused } \\
\text { purple proximally with } \\
\text { purple nerves; petals with } \\
\text { purple in the median area } \\
\text { white towards the margins; } \\
\text { lip white, spotted purple, or } \\
\text { purple, white towards the } \\
\text { margins and the apex }\end{array}$ \\
\hline Dorsal sepal & $\begin{array}{l}\text { Shortly attenuate, concave, } \\
0.9-1.0 \times 0.5-0.6 \mathrm{~cm} \text {, margins } \\
\text { denticulate and ciliate. }\end{array}$ & $\begin{array}{l}1.1-1.4 \times 0.6-0.9 \\
\mathrm{~cm} \text {, apex acuminate, } \\
\text { margins ciliate, } \\
\text { seven nerves. }\end{array}$ & $\begin{array}{l}0.7-0.72 \times 0.4-0.42 \\
\mathrm{~cm} \text {, entire, with } 5 \text { purple } \\
\text { nerves, obtuse }\end{array}$ & $\begin{array}{l}0.45-0.5 \times 0.3-0.42 \mathrm{~cm} \text {, } \\
\text { porrect or recurved, acute } \\
\text { to shortly acuminate, } \\
\text { margins short fimbriae } \\
\text { except near the base, with } \\
5 \text { purple nerves. }\end{array}$ \\
\hline $\begin{array}{l}\text { Lateral } \\
\text { sepals }\end{array}$ & $\begin{array}{l}\text { Narrowly triangular, elongate, } \\
\text { oblique, connivent along upper } \\
\text { apical half, } 2.6-3 \times 0.5-0.6 \mathrm{~cm}\end{array}$ & $\begin{array}{l}\text { Obliquely ovate- } \\
\text { lanceolate, } 1.9-2.5 \\
\times 0.6-0.8 \mathrm{~cm} \text {, acute, } \\
\text { lower margins con- } \\
\text { nate at the base, } \\
\text { seven nerves }\end{array}$ & $\begin{array}{l}\text { Oblong, } 1.2-1.3 \times \\
0.25-0.3 \mathrm{~cm} \text {, with } 5 \\
\text { nerves, obtuse, connate } \\
\text { along upper margin }\end{array}$ & $\begin{array}{l}\text { Oblique, oblong, } 1.4-2.0 \\
\times 0.3-0.45 \mathrm{~cm} \text {, porrect, } \\
\text { curved inwards at the base } \\
\text { and connate along the } \\
\text { upper margin }\end{array}$ \\
\hline Petals & $\begin{array}{l}\text { Ovate to broadly ovate, slightly } \\
\text { oblique, triangular, acute to acu- } \\
\text { minate, } 0.6-0.8 \times 0.4-0.5 \mathrm{~cm} \text {, } \\
\text { margins denticulate and ciliate, } 5 \\
\text { nerves }\end{array}$ & $\begin{array}{l}\text { Rotund-ovate, slight- } \\
\text { ly oblique, } 0.8-1.0 \\
\times 0.5-0.6 \mathrm{~cm} \text {, apex } \\
\text { rounded and mucro- } \\
\text { nate, margins entire } \\
\text { to minutely denticu- } \\
\text { late. }\end{array}$ & $\begin{array}{l}\text { Obliquely ovate, } 0.3- \\
0.31 \times 0.2-0.21 \mathrm{~cm}, \\
\text { acute to acuminate, } \\
\text { margins minutely ciliate, } \\
\text { keeled, } 3 \text { nerves with } \\
\text { purple apex }\end{array}$ & $\begin{array}{l}\text { Recurved, obliquely ovate- } \\
\text { triangular, } 0.42-0.55 \times \\
0.22-0.33 \mathrm{~cm} \text {, obtuse, } \\
\text { margins fimbriate, papil- } \\
\text { lose distally, } 3 \text { nerves }\end{array}$ \\
\hline Lip & $\begin{array}{l}0.5-0.6 \mathrm{~cm} \text { long, densely papillose } \\
\text { on adaxial surface, not grooved }\end{array}$ & $\begin{array}{l}0.8 \times 0.4-0.5 \mathrm{~cm}, \text { not } \\
\text { grooved }\end{array}$ & $\begin{array}{l}0.3 \times 0.1 \mathrm{~cm}, \text { base } \\
\text { grooved, prominent } \\
\text { median white ridge run- } \\
\text { ning from the base to } \\
\text { the apex }\end{array}$ & $\begin{array}{l}0.32-0.4 \times 0.19-0.25 \mathrm{~cm}, \\
\text { grooved, median ridge } \\
\text { most of the length }\end{array}$ \\
\hline
\end{tabular}




\begin{tabular}{l|l|l|l|l}
\hline Column & $\begin{array}{l}0.25-0.32 \mathrm{~cm} \text { long, foot up to } 0.7 \\
\mathrm{~cm} \text { long }\end{array}$ & $\begin{array}{l}\text { ca. } 0.3 \mathrm{~cm} \text { long, foot } \\
0.7-0.9 \mathrm{~cm} \text { long }\end{array}$ & $\begin{array}{l}\text { Column } 0.15 \mathrm{~cm} \text { long; } \\
\text { foot } 0.5 \mathrm{~mm} \text { long }\end{array}$ & $\begin{array}{l}0.16-0.2 \mathrm{~cm} \text { long; foot } \\
\text { adaxially with a median } \\
\text { tooth and } 2 \text { slight lateral } \\
\text { wings at the apex }\end{array}$ \\
\hline Stellidia & $\begin{array}{l}\text { Mucronate, slender, with small } \\
\text { triangular tooth above, broadly } \\
\text { triangular wing below, apex obtuse }\end{array}$ & $\begin{array}{l}\text { Subulate, slightly } \\
\text { downcurved, with } \\
\text { acute tooth above, } \\
\text { triangular wing be- } \\
\text { low, apex obtuse. }\end{array}$ & $\begin{array}{l}\text { Slender, pointing for- } \\
\text { ward, truncate tooth } \\
\text { above, triangular wing } \\
\text { bellow }\end{array}$ & $\begin{array}{l}\text { Porrect, triangular, acute, } \\
\text { with a small, pointing up- } \\
\text { ward, deltoid, acute tooth } \\
\text { along the upper margin } \\
\text { and a slight, deltoid round- } \\
\text { ed wing along the lower. }\end{array}$ \\
\hline Anther cap & $\begin{array}{l}\text { Hemispheric, yellowish to } \\
\text { yellowish-green }\end{array}$ & Ovoid & $\begin{array}{l}\text { Subglobose, papillose, } \\
\text { purple }\end{array}$ & Globose, purple \\
\hline Distribution & Endemic to Vietnam & $\begin{array}{l}\text { Hong Kong and } \\
\text { Vietnam }\end{array}$ & $\begin{array}{l}\text { India (Hamren of Karbi } \\
\text { Anglong, Assam) }\end{array}$ & Endemic to Borneo \\
\hline
\end{tabular}

Propagation Centre (ASSAM), Assam. All the photos were taken with a Canon 6D Mark-II fitted with an EF $100 \mathrm{~mm} \mathrm{f} / 2.8 \mathrm{~L}$ Macro USM lens. The terminology for the morphological description follows Beentje (2012).

\section{TAXONOMIC TREATMENT}

\section{Bulbophyllum karbianglongensis K.Gogoi \& R.Hondiqui, sp. nov.}

TYPE: India. Assam: Karbi Anglong District, Hamren, 500 m, 14 March 2018, (flowered in cultivation 20 April 2021), K. Gogoi and R. Hondiqui 00953 (holotype: Orchid Herbarium Tipi; isotype: ASSAM, Herbarium of the Orchid Society of Eastern Himalaya), (Fig. 1-3).

DiAgNosis: Bulbophyllum karbianglongensis resembles B. bicolor, B. venulosum, and B. blaoense but differs in clustered, narrowly ovoid to conic pseudobulb; elliptic-lanceolate leaves; flowers greenish-yellow with purple nerves, lip dark red/purple with a prominent median white band running from the base to the apex, dorsal sepal ovate-oblong, entire; stellidia slender, pointing forward, truncate tooth above, winged bellow. Detailed morphological differences between these species are presented in Table 1.

Plants epiphytic, pseudobulbous, pseudobulbs borne on creeping rhizome. Rhizome stout, short, ca. $0.5 \mathrm{~cm}$ diameter. Pseudobulbs clustered together, narrowly ovoid to conic, $1.5-2.5 \times 0.8-1.8 \mathrm{~cm}, 3$ bracts sheathing towards the base, with a terminal leaf. Leaves single, elliptic-lanceolate, 15.0-17.5 × 1.4-1.6 $\mathrm{cm}$, acute to acuminate, fleshy, petiolate; petiole $2 \mathrm{~cm}$ long, channeled. Inflorescence arising from the base of the pseudobulb, erect or sub-erect, longer than leaves, yellowish-green, bearing a subumbel of 5-10 flowers; peduncle slender, $c a$. $0.2 \mathrm{~cm}$ in diameter, $15-19 \mathrm{~cm}$ long, with 2 or 3 tubular sheaths; floral bracts greenish-yellow, lanceolate, $0.4-0.5 \times 0.1 \mathrm{~cm}$, acute, shorter than pedicel and ovary; pedicel (with ovary) $c a .1 \mathrm{~cm}$ long, slender. Flowers $1.4-1.5 \times 0.5-0.4 \mathrm{~cm}$, greenishyellow with purple nerves. Dorsal sepal ovate-oblong, concave, entire, 0.70-0.72 × 0.42-0.42 cm, 5-veined, apex obtuse. Lateral sepals oblong, 1.2-1.3 $\times 0.25-$ $0.30 \mathrm{~cm}, 5$-veined, apex obtuse, base adnate to column foot, twisted near the base, connate along upper margin. Petals obliquely ovate, $0.30-0.31 \times 0.20-0.21$ $\mathrm{cm}$, apex acute to acuminate, margins minutely ciliate, keeled, 3-veined, with purple apex. Lip dark red/ purple with a prominent median white band running from the base to the apex, recurved, ligulate, $0.3 \times 0.1$ $\mathrm{cm}$, fleshy, base grooved, attached to the column foot by a mobile joint, side lobes inconspicuous. Column ca. $0.15 \mathrm{~cm}$, stellidia slender protruding forward, $c a$. $0.05 \mathrm{~cm}$ long, upper with small tooth for each side, the lower margin of column broadly winged; foot $0.15 \mathrm{~cm}$, upcurved. Pollinia $0.05 \mathrm{~cm}$, yellow, anther cap subglobose, papillose, $0.1 \times 0.1 \mathrm{~cm}$, purple.

FLOWERING PERIOD: May to June.

HАвiтAт: On tree trunks in tropical mixed evergreen forest at 400-500 m in Karbi Anglong, Assam.

Distribution: India (Hamren of Karbi Anglong, Assam) (Fig. 1A).

Eтymology: The specific epithet refers to the "Karbi Anglong" district of Assam, in Northeast India, where the plant was collected. 


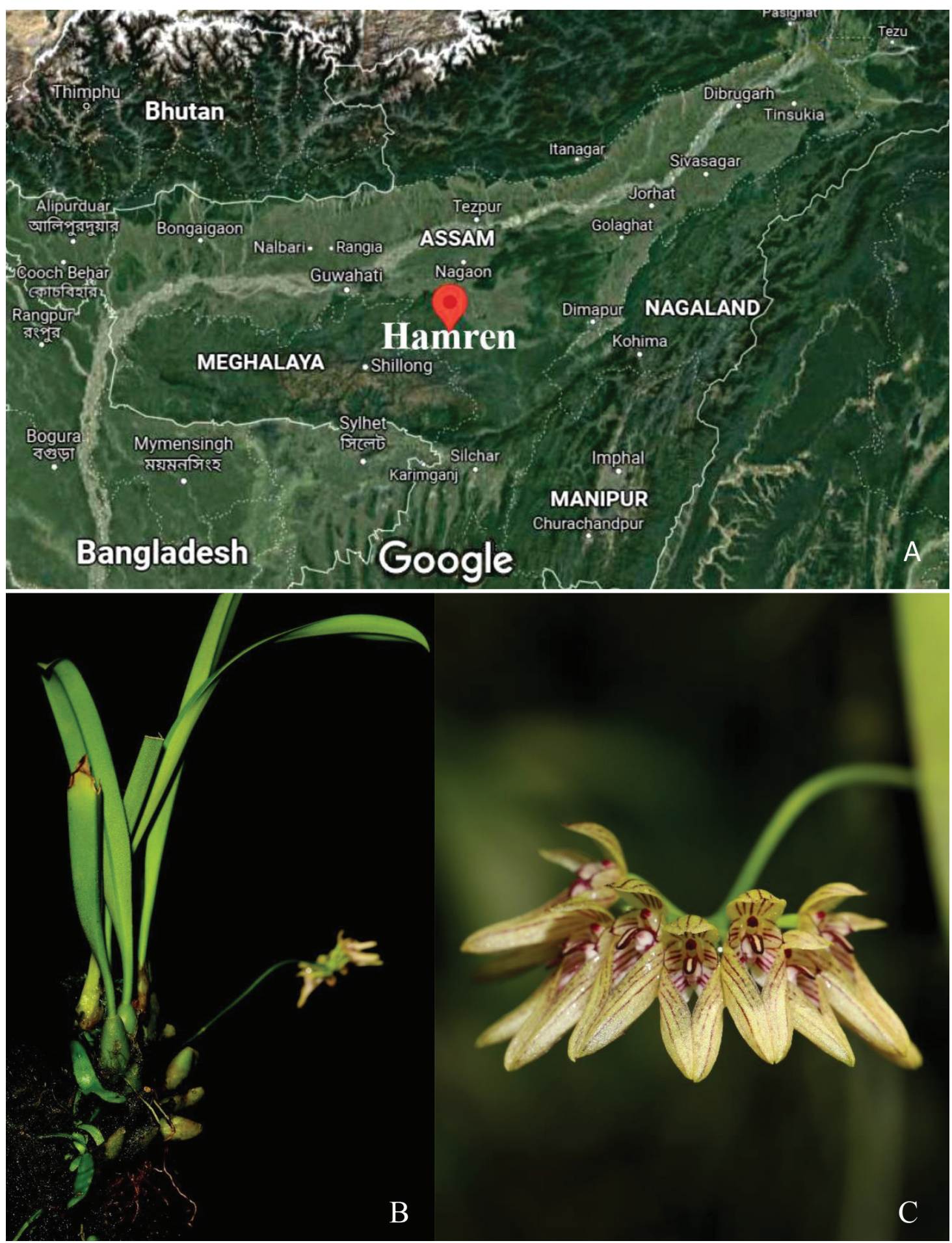

FIgURE 1. A. Distribution map of Bulbophyllum karbianglongensis. B. Habit of Bulbophyllum karbianglongensis. C. Bulbophyllum karbianglongensis inflorescence. Photos by K. Gogoi. 


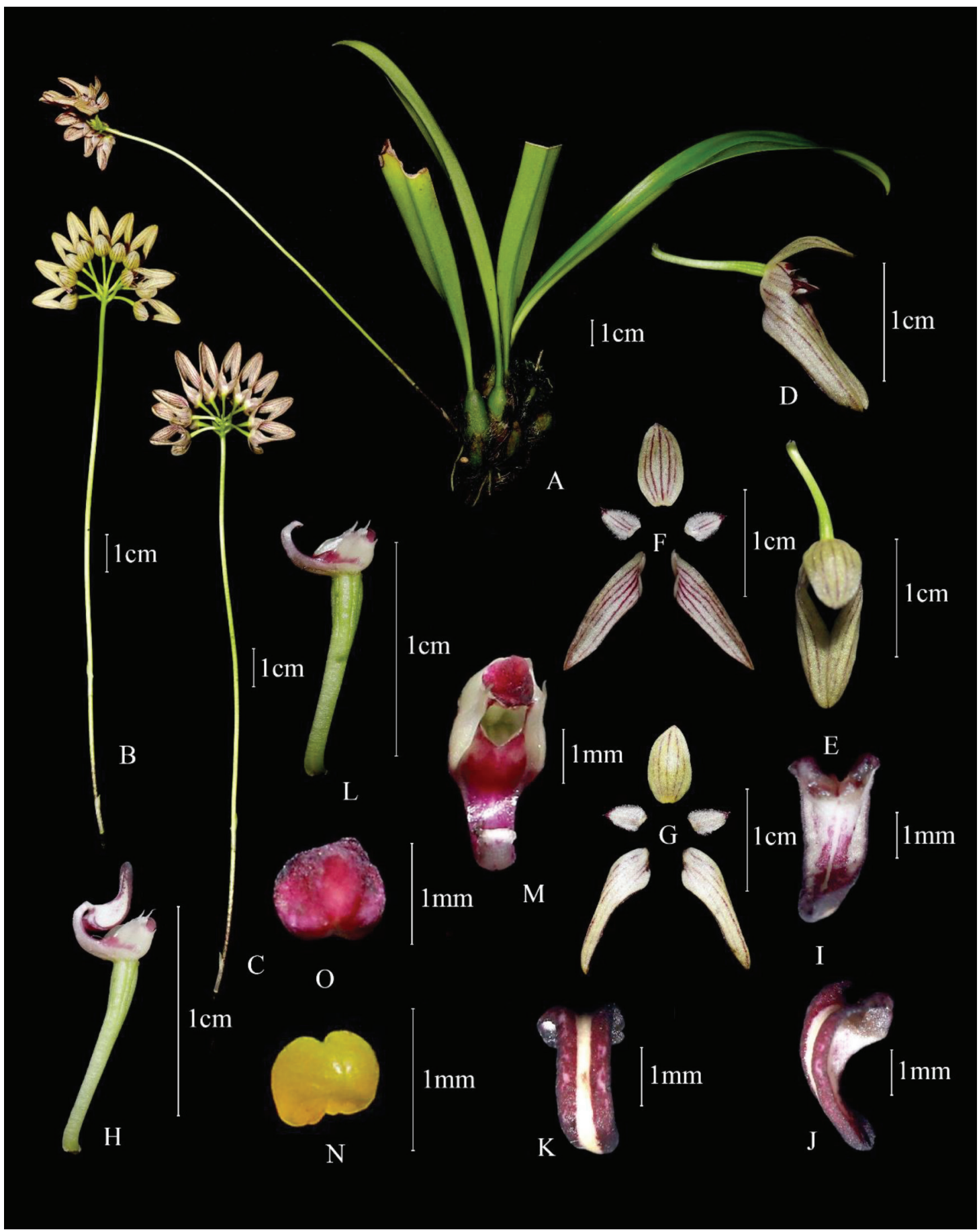

Figure 2. Bulbophyllum karbianglongensis. A. Habit. B. Ventral view of inflorescence. C. Dorsal view of inflorescence. D. Side view of flowers. E. Ventral view of flower. F. Ventral view of perianth. G. Dorsal view of perianth. H. Lip with ovary and column. I. Dorsal view of lip. J. Side view of lip. K. Ventral view of lip. L. Ovary with pedicel and column. M. Front view of column. N. View of pollinarium. O. Anther cap ventral view. Photos by K. Gogoi. 


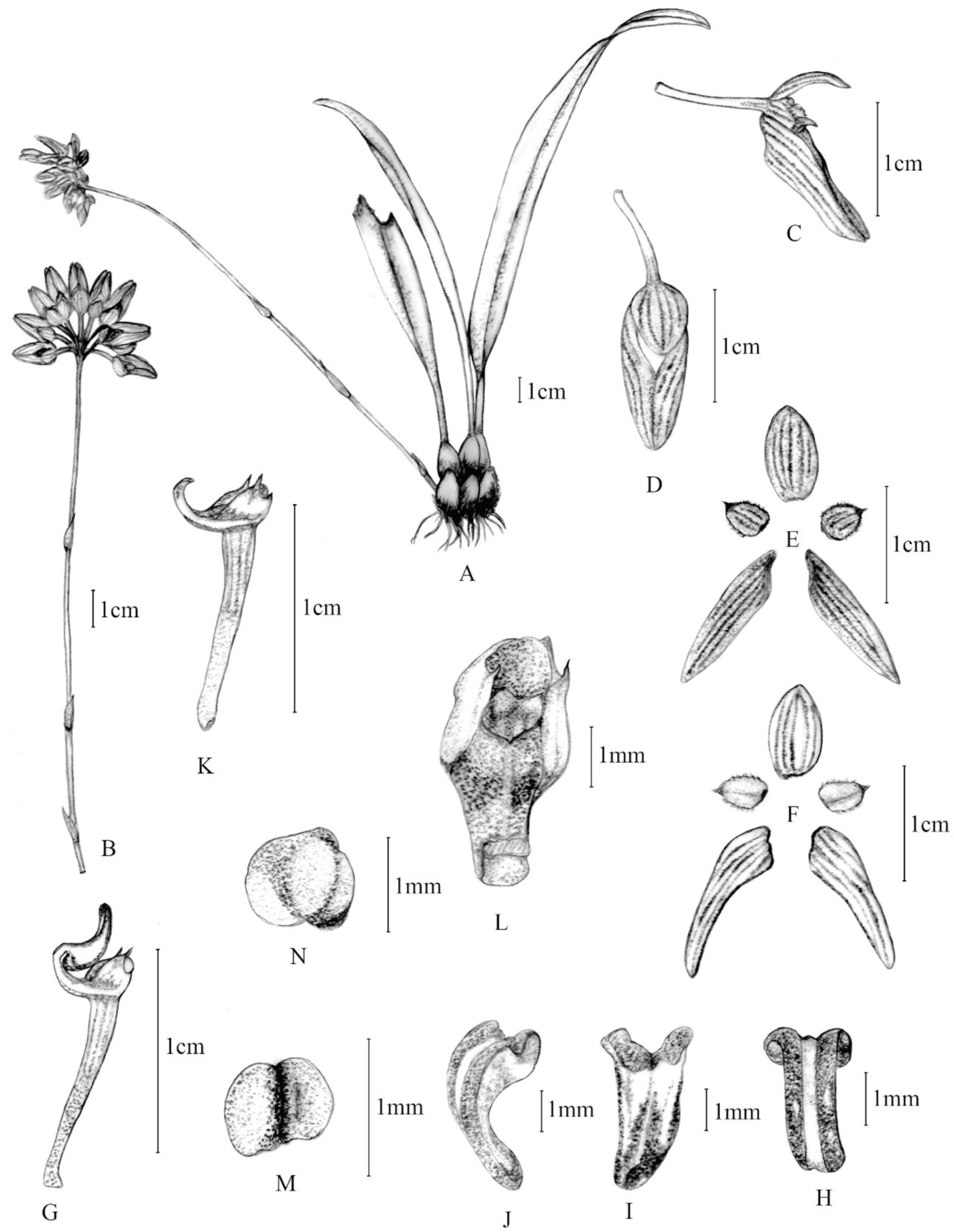

Figure 3. Bulbophyllum karbianglongensis A. Habit. B. Ventral view of inflorescence. C. Side view of flowers. D. Ventral view of flower. E. Ventral view of perianth. F. Dorsal view of perianth. G. Lip with ovary and column. H. Ventral view of lip. I. Dorsal view of lip. J. Side view of lip. K. Ovary with pedicel and column. L. Front view of column. M. View of pollinarium. N. Anther cap ventral view. Drawing by K. Gogoi. 
Acknowledgements. The authors are grateful to Dr. Pankaj Kumar, Kadoorie Farm and Botanic Garden (KFBG) Corporation, Hong Kong S.A.R. (P.R. China) and Ba Vuong Truong, Institute of Tropical Biology, Vietnam Academy of Science and Technology (Vietnam) for providing literature and valuable suggestion during identification of the species.

\section{LITERATURE CITED}

Averyanov, L. V., Nguyen, K. S., Tich, N. T., Nguyen, P. T., Nong, V. D., Nguyen, V.C. \& Xuan, C. C. (2015). New orchids in the flora of Vietnam. Wulfenia, 22, 137-188.

Beentje, H. (2012). The Kew Plant Glossary, an illustrated dictionary of plant terms (revised edition). Kew: Royal Botanic Gardens, Kew Publishing.

Chen, X. Q., Liu, Z. J., Zhu, G. H., Lang, K. Y., Ji, Z. H., Luo, Y. B., Jin, X. B., Cribb, P. J., Wood, J. J., Gale, S. W., Ormerod, P., Vermeulen, J. J., Wood, H. P., Clayton, D. \& Bell, A. (2009). Orchidaceae. In Z. Y. Wu, P. H. Raven \& D. Y. Hong (Eds.), Flora of China, volume 25 (pp. 1-506). St. Louis: Missouri Botanical Garden Press.

Chowdhery, H. J. (1998). Orchid Flora of Arunachal Pradesh. Dehra Dun, India: Bishen Singh Mahendra Pal Singh.

Gale, S., Wang, J. \& Williams, M. I. (2010) Bulbophyllum bicolor Orchidaceae. Curtis's Botanical Magazine, 27(4), 328-338.

Gogoi, K. (2014). Orchids of Garampani Wildlife Sanctuary, Karbi Anglong district, Assam (Part-I). The McAllen International Orchid Society Journal, 15(6), 8-16.

Gogoi, K. (2014). Orchids of Garampani Wildlife Sanctuary, Karbi Anglong district, Assam (Part-II). The McAllen International Orchid Society Journal, 15(7), 11-24.

Gogoi, K. (2018). Wild Orchids of Assam - A Pictorial Guide. Guwahati, Assam: Assam State Biodiversity Board.

Gogoi, K. (2019). Orchids of Assam - A Pictorial Guide. Dibrugarh, Assam: Dibrugarh University.

Gogoi, K. \& Yonzone, R. (2013a). Orchids of The Karbi Anglong District of Assam, India. (Part-I). The McAllen International Orchid Society Journal, 14(4), 11-20.

Gogoi, K. \& Yonzone, R. (2013b). Orchids of The Karbi
Anglong District of Assam, India (Part-II). The McAllen International Orchid Society Journal, 14(5), 2-20.

Gogoi, K. \& Yonzone, R. (2013c). Orchids of The Karbi Anglong District of Assam, India (Part-III). The McAllen International Orchid Society Journal, 14(6), 5-16.

Hegde, S. N. revised by Tam, N., Tsering, J. \& Apang, O. (2017). Orchids of Arunachal Pradesh. Itanagar, India: Department of Environment and Forest, Govt. of Arunachal Pradesh.

Hooker, J. D. (1888). Orchideae. In: Flora of British India. Ashford, Kent, 5, 667-858.

King, G. \& Pantling, R. (1898). The orchids of the Sikkim Himalayas. Annals of the Royal Botanical Garden Calcutta, 8, 1-342, tt. 1-448.

Lucksom, S. Z. (2007). The Orchids of Sikkim and North East Himalaya. Gangtok, East Sikkim, India: Development Area, Jiwan Thing Marg.

Misra, S. (2019). Orchids of India- a hand book. Dehra Dun, India: Bishen Singh Mahendra Pal Singh.

Pearce, N. R. \& Cribb, P. J. (2002). Orchids of Bhutan: Flora of Bhutan. Vol. 3, No. 3. Edinburg: Royal Botanical Garden.

Pradhan, U.C. (1979). Indian Orchids Guide to Identification and Culture, Vol II. (pp. 190-747). Faridabad, India: Thomson Prass.

Rao, A.N. (2010). Orchid flora of North East India, An upto-date analysis. Bulletin of Arunachal Forest Research, 23(1\&2), 6-38.

Singh, S. K., Agrawala, D. K., Das, S. S., Mao, A. A. \& Singh, P. (2019). Orchids of India- A pictorial guide. Kolkata, India: Botanical Survey of India, Ministry of Environment, Forest \& Climate change.

Petit-Thouars \& Du, A.A. (1822) Histoire particuliere des plantes orchidees recueillies sur les trois îles australes d'Afrique, de France, de Bourbon et de Madagascar. Petit-Thouars, Paris. http://dx.doi.org/10.5962/bhl. title.492

Vermeulen, J. J., Fischer, G., Camargo, E. de S., Stern, W. L., Pridgeon, A. M., Veitch, C., Sieder, A., Vugt, R., Gravendeel, B. (2014). Bulbophyllum. In A. M. Pridgeon, P. J. Cribb, M. W. Chase \& F. N. Rasmussen (Eds.), Genera Orchidacearum 6, Epidendroideae pt. 3 (pp. 4-51). Oxford, UK: Oxford University Press. 
LANKESTERIANA 